\title{
留 \\ PARTAI KEAGAMAAN DALAM KOMPETISI POLITIK DI DUNIA BARAT DAN MUSLIM
}

\author{
Henry Iwansyah \\ IAIN Raden Intan Lampung \\ Henry_iwansyah@yahoo.com
}

\begin{abstract}
Abstrak
Tulisan ini menganalisis perkembangan partai-partaipolitik keagamaan di tingkat dunia. Tujuannya adalah untuk mengetahui apakah partaipartai berbasis keagamaan, khususnya Islam dan Kristen, mampu bertahan dalam menghadapi proses modernisasi dan sekulerisasi yang telah melanda dunia. Untuk itu, tulisan ini menelaah sejumlah partai politik, baik di negara-negara mayoritas Muslim maupun Kristen, khususnya dalam hal kemampuan mereka dalam menarik dukungan massa pada setiap even pemilu. Hasilnya menunjukkan bahwa perolehan suara partai-partai itu, baik yang ada di negara-negara Barat maupun Muslim, terus mengalami kemerosotan. Jika kondisi semacam ini tidak segera diatasi, dikhawatirkan bahwa kehadiran partai-partai keagamaan dalam panggung politik masa depan akan hilang.
\end{abstract}

\begin{abstract}
Abstrak
This paper analyses the development of religious political parties in the world. The aim is to determine whether the parties based on religion, particularly Islam and Christianity, are able to survive in the face of modernization and secularisation process that has swept the world. To that end, this paper examines a number of political parties, both in the Muslim and Christian countries, especially in terms of their ability to attract masssupport in every election event. The results indicate that the votes of these parties, both in Western and Muslim countries, continue to decline. If such conditions are not addressed, it is feared that the presence of religious parties in the political arena of the future will be lost.
\end{abstract}

Kata kunci : Partai, Politik, keagamaan, Barat, Islam. 


\section{A. Pendahuluan}

Partai politik memiliki kedudukan dan fungsi yang penting dalam kehidupan politik dan ketatanegaraan. Seperti ditegaskan oleh Key, organisasi ini adalah institusi utama untuk menerjemahkan keinginan publik ke dalam kebijakan publik. ${ }^{1}$ Satusatunya organisasi, demikian Schattscheneider menegaskan, yang dapat menerjemahkan ide-ide kepemimpinan mayoritas ke dalam suatu kenyataan adalah partai. ${ }^{2}$ Partai menciptakan demokrasi modern dan demokrasi modern tidak dapat terbayangkan tanpa keterkaitannya dengan partai. ${ }^{3}$ Mirip dengan pernyataan ini, 'Abd al-Hāmid Ismā'il al-Ansarìy menegaskan bahwa partai merupakan landasan demokrasi. Demokrasi tidak dapat hidup tanpa partai, sebaliknya partaipun tidak dapat hidup tanpa demokrasi. ${ }^{4}$

Kendati peran partai dalam kehidupan politik dan ketatanegaraan sedemikian urgen, namun sebagai suatu organisasi, partai politik banyak menghadapi tantangan dan kendala yang menyebabkan organisasi itu mengalami masa pasang surut.

Artikel ini mencoba memotret perkembangan partai-partai politik berbasis agama di sejumlah negara mayoritas Kristen dan Muslim untuk memperoleh gambaran bagaimana keberadaan organisasi tersebut dalam dinamika sosial dan politik, sekaligus mengidentifikasi beberapa faktor tertentu yang berada di balik perkembangan tersebut.

\section{B. Tinjauan Umum tentang Partai}

Di dalam bahasa Arab, istilah "partai" dikenal dengan kata hizb atau ahzāb (pl). Menurut penulis kitab Lisān al-'Arab, kata hizb/ahzāb memiliki sejumlah makna di antaranya: kumpulan

${ }^{1}$ Valdimer O. Key Jr., Public Opinion and American Democracy (New York : Knopf, 1961), h. 433.

${ }^{2}$ Elmer E. Schattscheneider, The Struggle for Party Government (College Park MD : University of Maryland, 1948), h. 10

${ }^{3}$ Elmer E. Schattsscheneider, Party Government in the United States, (New York: Holt Rinehart and Winston, 1942), h. 1; Bandingkan dengan Clinton Rositer, Parties and Politics in Americ, (Ithaca, NY : Cornell University Press, 1960), h. 1.

4 'Abd al-Hāmid Ismā îl al-Ansarìy, Al-Sūra wa Atharuha fi al-Dỉmuqrātiyah, (Beirut: Mansurāt al-Maktabah al-Ahdiyah, tt.), h. 368. 
orang, jama'ah, tentara, bacaan (wirid), bagian (perolehan), kelas dalam masyarakat, dan lain-lain. ${ }^{5}$

Di dalam al-Quran istilah hizb/ahzāb juga dapat ditemui dalam sejumlah ayat dengan makna yang beragam. Di dalam surah al-Mā'idah: 56, misalnya, kata hizb bermakna: pengikut agama; Di dalam surah al-Mu'minūn: 53; surah al-Rūm: 32; surah al-Mujādilah: 19, 22; dan di beberapa tempat lain, kata hizb/ahzāb memiliki makna: golongan; Di dalam surah Hūd: 17 kata ahzāb bermakna: kaum kafir Quraish dan sekutu-sekutunya; Di dalam surah al-Ra'du: 36, kata ahzāb bermakna: orang-orang Yahudi dan Nasrani; Di dalam surah al-Zukhruf: 65 kata ini bermakna: kaum Nasrani dari kelompok Nestoria, Jacobit, dan Malkaniah; Di dalam surah Shad: 11 kata tersebut bermakna: kaum musyrik dari kabilahkabilah Arab yang bersekutu dengan orang-orang Yahudi; Di dalam surah Shad: 13 dan surah al-Mu'min: 5, 30, kata itu menunjuk kepada: kaum-kaum terdahulu yang ingkar seperti: kaum Nūh, 'Ād, Fir'aun, Samūd, Lūt, Aikah dan sesudahnya.

Menurut beberapa penulis Arab, fenomena partai pertama kali muncul di dunia Islam pada masa kekhalifahan 'Ali bin Abi Tālib yang ditandai dengan munculnya sekelompok oposan yang dikenal dengan nama Khawārij. ${ }^{6}$ Sementara di Barat, fenomena partai (party) pertama kali muncul di Inggris pada akhir abad ke-17 seperti terekam dalam tulisan Viscount Bolingbroke I (1678-1751) yang hidup semasa dengan Montesquieu (1689-1755). ${ }^{7}$

${ }^{5}$ Muhammad ibn Manzūr, Lisan al-AArab, (Beirut: Dār al-Sādir, 1956), Juz I, h. 308-309.

${ }^{6}$ Hasan Ibrāhim Hasan, Tārīkh al-Islām al-Siyāsỉ wa al-Dỉnỉ wa al-Tsaqāfi wa al-Ijtimāîy (Kairo: Maktabah al-Nahd \{ah al-Mis\{riyyah, 1996), Juz II, h. 7-10. Baca pula: Husain Jahād al-Hassānỉ dan Najāh Jābir al-Husainī, Mashrū'iyah al-Ahzāb fi al-Islām fi Tanzỉri Ayat Allah al-Karabāsī, (Beirut: Bait al-'Ulūm li al-Nābihin, 2006), h. 42, dan Muhammad 'Imārah, al-Islām wa Falsafah al-Hukm, (Kairo: Dār al-Shurūq, 1989), h. 116-117. Bandingkan dengan Bakr ibn 'Abdillah Abū Zaid, "Hukm al-Intimā'i ilā al-Farq wa al-Ahzāb wa al-Jamā‘āh al-Islāmiyah”, al-Ri'āsah al-'Āmmah li Idārāt alBuhūts al-AAlamiyyah wa al-Iftā'i wa al-Da‘wah wa al-Irshād, No. 33/2 (1989), h. 21.

${ }^{7}$ Baca Giovanni Sartori, Parties and Party Systems: A Framework for Analyses, (Colchester: ECPR Press, 2005), h. 5 dan 26. Untuk lebih lengkap baca Caroline Robbins, "Discordant Parties": A Study of the Acceptance of Party by Englishmen," Political Science Quarterly, vol. 73, no.4 (Dec.1958), h. 505-529 dan Joseph A. Schlesinger, "Political Party Organization" dalam James G. March (ed) Handbook of Organizations, (Chicago: Rand McNally, 1965), h. 764-801. 
Namun jika diperhatikan dengan seksama, konsep "hizb/ ahzāb/party" yang dipergunakan untuk menandai fenomena di atas berbeda dengan konsep "partai" yang muncul dan popular sekitar pertengahan abad ke-19. Perbedaan ini ditandai dengan absennya elemen-elemen keanggotaan, keorganisasian, ideologi dan elektoral pada "partai" dalam kategori pertama, yang pada kategori ke-dua elemen-elemen itu justru merupakan unsur utamanya. Ini berarti bahwa ada dua pengertian yang terkandung dalam istilah "partai/ hizb/party”, yakni pengertian yang mengacu kepada fenomena yang muncul sebelum abad ke-19 dan fenomena yang datang setelah pertengahan abad ke-19. Karena itulah, agar tidak terjadi kesalahfahaman para penulis Arab kemudian menambahkan kata "al-siyāsiyah" sesudah kata hizb/ahzāb, seperti halnya para penulis Barat menambahkan kata "political" sebagai adjektif dari istilah "party/parties".

Di dalam literatur Arab, istilah al-ahzāb al-siyāsiyah (partai politik) didefinisikan oleh para penulis secara beraneka ragam. Tāriq 'Alial-Hāshimì mengartikan istilah tersebut sebagai "sekelompok orang yang berhimpun dalam suatu organisasi tertentu, atas dasar kepentingan dan prinsip-prinsip tertentu, dengan tujuan untuk mencapai otoritas atau berpartisipasi di dalamnya. ${ }^{8}$ Penulis kitab Mukhtasor al-Tsaqāfah al-Siyāsiyah mendefinisikannya sebagai "kumpulan individu yang percaya dengan target-target politis dan ideologi yang kemudian secara bersama-sama mengorganisir diri untuk mencapai tuntutan dan tujuan tertentu. ${ }^{9}$ Sedangkan Sofi alRahman al-Mubārakafūrī, sebagaimana dikutip oleh Solāh al-Sāwỉ, memahami partai politik sebagai " suatu organisasi yang didirikan atas dasar pandangan dan pendirian politik yang oleh sekelompok politisi dipandang sebagai sesuatu yang wajib dihormati dan dilaksanakan guna mengatur kehidupan politik dan kemasyarakatan dalam suatu negara". ${ }^{10}$

${ }^{8}$ Tāriq 'Ali al-Hāshimì, al-Ahzāb al-Siyāsiyah, (Baghdād: Sharikah al-Tab'i wa al-Nashr, 1968), h. 64-65.

${ }^{9}$ Fahd ibn 'Abd Allah al-Rabỉ'ah al-Mālikỉ dan Mubārak ibn 'Abd Allah al-Rabì'ah al-Māliki, Mukhtasor al-Tsaqāfah al-Siyāsiyah, (Yordan: Dār ibn al-Jawzì, 2013), h. 82.

${ }^{10}$ Solāh al-Sāwī, Tā‘addudiyah al-Siyāsiyah fi Dawlah al-Islmiyah, (Kairo: Dār al-I'lām al-Dawli, 1993), h. 4. 
Di kalangan para penulis Barat, kata "political party" pun didefinisikan secara beragam. Definisi yang paling klasik adalah dari Edmund Burke, seperti dikutip oleh Lapalombara dan Anderson, yang mengartikan partai sebagai “ suatu kumpulan kaum pria yang bersatu untuk memperjuangkan, melalui usaha bersama mereka, kepentingan nasional atas prinsip-prinsip tertentu yang mereka semua menyetujuinya. ${ }^{11}$ Anthony Down mendefinisikan partai politik sebagai " suatu koalisi manusia yang berupaya untuk memegang kontrol terhadap aparat pemerintahan melalui perolehan kekuasaan berdasarkan pemilihan umum yang sepatutnya. ${ }^{12}$ Leon D. Eipstein mendefinisikannya sebagai “ setiap kelompok, betapapun kendur ikatan organisasinya, yang berupaya untuk memilih pemegang jabatan pemerintahan di bawah label tertentu". ${ }^{13}$

Fenomena partai dapat diklasifikasikan kepada beberapa tipologi; Untuk itu para teoritikus telah membuat sejumlah model klasifikasi partai berdasarkan tipologi tertentu. Namun, seperti dikeluhkan oleh André Krouwel, kebanyakan model yang diajukan menggunakan pendekatan berdimensi tunggal atau hanya berfokus pada aspek organisasi saja. Banyak model tidak memasukkan indikator empiris, yang memungkinkan orang untuk menentukan partai-partai mana yang secara nyata masuk dalam kategori tertentu, termasuk ketika partai-partai itu berubah menjadi suatu tipologi baru yang berbeda. ${ }^{14}$ Lebih jauh lagi, seperti ditegaskan oleh Gunther dan Diamond, kebanyakan dari model/tipologi yang ada secara konseptual memiliki kemampuan jelajah yang terbatas, karena hanya didasarkan kepada fenomena yang ada di kawasan Eropa atau di Amerika sekitar satu atau satu setengah abad yang lampau, dan tentu saja tidak sesuai lagi dengan kondisi dan situasi

${ }^{11}$ Joseph Lapalombara dan Jeffrey Anderson, “ political parties” dalam Mary Hawkesworth dan Maurice Kogan (eds), Encyclopedia of Government and Politics, Vol. I, (London: Routledge, 1992), h. 394.

${ }^{12}$ Anthony Downs, An Economic Theory of Democracy, (New York : Harper and Row, 1957), h. 24-25.

${ }^{13}$ Leon D. Epstein, Political Parties in Western Democracies, (New Brunswick NJ: Transaction Publishers, 2000), h. 9.

${ }^{14}$ André Krouwel, "Party Models," dalam Richard S. Katz dan William J. Crotty (eds), Handbook of Party Politics, (London: Sage Publication Ltd., 2006), h. 249252. 
sekarang. Tegasnya, kebanyakan model/tipologi yang muncul lebih bersifat ad hoc, berbasis kriteria yang beraneka ragam, dan seringkali tidak konsisten. ${ }^{15}$

Ada beberapa cara yang telah ditempuh oleh para ilmuwan politik dalam mengklasifikasikan partai. Pertama, dengan cara membedakan asal muasal kelahiran (intra/extra parliament). Cara ini dipakai oleh Duverger, ${ }^{16}$ dan merupakan cara yang paling mudah karena hanya mendasarkan lewat jalur mana inisiatip pendirian suatu partai muncul (dari dalam/luar parlemen).

Kedua, dengan cara membuat tipologi berdasarkan kecenderungan/tujuan utama partai yakni : vote-seeking (mengejar perolehan suara), policy-seeking (mengejar kebijakan) dan office-seeking (mengejar posisi di pemerintahan). Cara ini dipergunakan Wollinetz ketika ia merumuskan enam macam tipologi partai. ${ }^{17}$

Ke-tiga, dengan cara membuat daftar semua partai yang ada, lalu mengenali karakter pokoknya masing-masing untuk kemudian memasukkannya ke dalam beberapa model yang berbeda. Cara ini ditempuh oleh Katz dan Mair yang mengajukan empat model partai yakni: partai elite (elite party), partai massa (mass party), partai raihsemua (catch-all party) dan partai kartel (cartel party). ${ }^{18}$

Ke-empat, dengan cara membuat bagan "genera" yang memuat tipe partai mana saja yang telah berkembang dari "genus" tertentu. Cara ini dilakukan oleh Gunther dan Diamond yang mengembangkan lima belas species partai dari lima "genera".

\footnotetext{
${ }^{15}$ Richard Gunther dan Larry Diamond, "Species of Political Parties : A New Typology,” Party Politics, vol. 9, no. 2 (2003), h. 167-168.

${ }^{16}$ Maurice Duverger, Political Parties : Their Organization and Activity in the Modern State, (London : Methuen, 1959), h. xxx.

${ }^{17}$ Wollinetz membagi partai berdasarkan atas tujuan ke dalam 6 tipe : 1 . Catch-all/electoral professional party, 2. Programmatic party, 3. Patronage-oriented party, 4. New politics party, 5. Party of mass integration, 6. Cartel party, Baca Steven B. Wollinetz, "Beyond the Catch-All Party: Approaches to the Study of Parties and Party Organization in Contemporary Democracies," dalam Richard. Gunther, J. Ramon-Montero, dan Juan J. Linz, (eds). Political Parties: Old Concepts and New Challenges, (Oxford: Oxford University Press, 2002), h. 161.

${ }^{18}$ Richard S. Katz dan Peter Mair, "Changing Models of Party Organization and Party Democracy: The Emergence of the Cartel Party," dalam Party Politics, vol. 1, no. 1, (1995), h. 1-18.
} 
Ke-lima, adalah dengan membuat klasifikasi berdasarkan klaster. Cara ini diterapkan oleh Krouwel yang membagi modelmodel partai ke dalam lima klaster yakni: (1) Klaster partai-partai kader, kaukus dan elite [elite, caucus and cadre parties (1860-1920)]; (2) Klaster partai-partai massa [mass-parties (1880-1950)], (3) Klaster partai-partai elektoralis dan raih-semua [cath-all, electoralists parties (1950-sekarang)], (4) Klaster partai-partai kartel [cartel parties. (1950sekarang)]; (5) Klaster partai-partai perusahaan-bisnis [business-firm parties (1990-sekarang)]. Dengan menggunakan lima klaster ini Krouwel kemudian mengklasifikasikan sejumlah 34 tipe partai ke dalam masing-masing klaster.

Fenomena partai juga dapat dirinci ke dalam beberapa bentuk yang lain. Katz dan Mair telah mengidentifikasi tiga wajah organisasi partai yakni : (1) Party on the ground- partai dalam arti keanggotaan, (2) party in central office- partai dalam arti organisasi, (3) party in public office- partai dalam bentuk perwakilan di lembaga pemerintahan (kabinet/parlemen). ${ }^{19}$ Mirip dengan ini, Valdimer O. Key, seperti dikutip oleh Maisel dan Brewer, membedakan partai pada tiga bentuk : party in the electorate,- para pendukung yang melekatkan diri pada suatu partai; party organization- struktur formal dari partai yang terdiri dari pemimpin dan para elite; party in government- para utusan/kandidat partai yang menduduki posisi di lembaga pemerintahan. ${ }^{20}$

Organisasi partai berkembang melalui pola-pola tertentu. Krouwel mengasumsikan bahwa perkembangan partai mengikuti fase/alur kronologi yang saling berkait (inter-connected). Menurutnya, partai elite/partai kader, yang muncul dalam fase pertama (18601920), lahir atas inisiatif individu-individu yang merupakan representasi dari para konstituen lokal di parlemen. Individuindividu ini merasa perlu untuk mengkordinasikan pekerjaan mereka di parlemen dengan komunitas di luar parlemen sebagai bagian dari usaha kampanye mereka.

${ }^{19}$ Richard S. Katz dan Peter Mair "The Evolution of Party Organization in Europe : The Three Faces of Party Organization "dalam The American Review of Politics 14 (1993), h. 593-617.

${ }^{20}$ Louis S. Maisel dan Mark D. Brewer, Parties and Elections in America: The Electoral Process, (Lanham, Maryland: Rowman \& Littlefield Publishers Inc., 2011), h. 11 . 
Bersamaan dengan itu, di luar parlemen, muncul upaya kolektif langsung dari masyarakat sipil untuk memobilisasi kelompok sosial, kebanyakan dalam bentuk serikat pekerja atau komunitas keagamaan, sebagai reaksi dari eksklusi politik yang dilakukan oleh kaum elite melalui partai-partai kadernya. Pada fase inilah (1880-1950) muncul "partai massa (mass party)".

Setelah partai massa berhasil melakukan proses integrasi politik antara elite partai dengan para pengikutnya, perkembangan partaipun lalu masuk ke fase ke-tiga (1950-sekarang). Di sini, partai massa mengalami transformasi menjadi suatu organisasi politik yang oleh Kirchheimmer dinamakan "partai raih-semua (catch-all party)". ${ }^{21}$ Dengan formasinya yang baru, elite-elite "partai raihsemua" selanjutnya secara perlahan-lahan memprofesionalkan organisasi mereka, memoderasi tuntutan politis dan sosial, dan mulai tampil ke kalangan pemilih yang berada di luar dari elektoral inti mereka sebelumnya.

Dengan makin kokohnya posisi "partai raih-semua" di parlemen, demikian Krowel melanjutkan, program-program partai yang satu dengan lainnya menjadi saling bertukar dan cenderung seragam. Akibatnya, partai-partai yang tadinya saling berhadapan secara politis cenderung melakukan kerjasama terutama dalam memanfaatkan fasilitas negara. Pada fase inilah (1950-sekarang) lalu muncul model partai baru yang dinamakan "partai kartel (cartel party)". Dalam perkembangannya, partai jenis baru ini secara perlahan-lahan mulai memonopoli sumber daya negara, memperkokoh lingkungan legalitas guna mendukung keberadaan dan kekuasaan mereka, serta mendiskriminasi kompetitornya yang baru. Strategi ini membuat mereka makin kuat dan menjadi sulit untuk ditembus oleh aktor/kelompok politik yang baru.

Sebagai reaksi dari kecenderungan eksklusi ini, muncullah apa yang disebut Krouwel sebagai "partai perusahaan-bisnis (businessfirm parties)" (1990-sekarang). Kelahiran dari model yang ke-lima dalam tipologi Krouwel ini ditandai dengan mulai aktifnya para petualang politik yang berasal dari kalangan bisnis dan korporasi

${ }^{21}$ Otto Kirchheimmer, "The Transformation of the West European Party Systems", dalam Joseph La Palombara dan Myron Weiner (eds), Political Parties and Political Development, (Princeton, N.J.: Princeton University Press, 1966), h. 253. 
untuk mencari akses ke arena elektoral dan pemerintahan. Para aktor politik yang baru muncul ini, karena tidak memiliki akses ke sumber-sumber formal di pemerintahan, selanjutnya memberdayakan sumber-sumber di sektor swasta dan menyusun strategi agar mereka dapat menembus pasar elektoral. ${ }^{22}$

Berbeda dengan Krouwel yang menggambarkan perkembangan partai sebagai suatu rangkaian kronologis, Katz dan Mair justru melihat perkembangan itu sebagai suatu proses dialektika. Menurut mereka, partai-partai itu lahir sebagai suatu mata rantai reaksi terhadap hubungan segitiga yakni antara partai politik, masyarakat sipil dan negara. ${ }^{23}$ Dengan kata lain, Katz dan Mair tidak melihat adanya hubungan kronologis antara model partai yang terdahulu dengan model yang datang sesudahnya, tetapi lebih meyakini bahwa model-model itu terbentuk pada suatu periode tertentu sebagai akibat hubungan timbal balik antara partai, pemerintah dan lingkungan elektoralnya.

\section{Partai Keagamaan dalam Perspektif Keilmuan}

Muḥammad Amān dan Sawì Sālim mendefinisikan "partai keagamaan /al-ahzāb al-dinniyah sebagai: partai-partai yang berdiri di atas asas keagamaan dan dengan konsep-konsep politik. ${ }^{24}$ Rosenblum mendefinisikan partai agama sebagai “ partai yang muncul ke hadapan para pemilih atas dasar keagamaan dan menarik inspirasi mereka dari nilai-nilai keagamaan, jika bukan teologi. ${ }^{25}$ Hakan Yavuz mendefinisikannya sebagai "partai yang muncul dari atau dibentuk oleh ide-ide keagamaan, dan yang memobilisasi masyarakat akar rumput atas dasar kesamaan identitas keagamaan. ${ }^{26}$ Hamayotsu memandang partai keagamaan sebagai “ partai politik yang berdasar kepada ideologi keagamaan, didirikan dan dipimpin oleh pimpinan keagamaan dan/atau yang dapat diasosiasikan dekat dengan organisasi keagamaan, menampakkan tingkat

${ }^{22}$ André Krouwel, “Party Models,”..., h. 261-264.

${ }^{23}$ Richard S. Katz and Peter Mair (1995), "Changing Models..., h. 5-28.

${ }^{24}$ Muhammad Amān dan Shawị Sālim, Tasnif Dỉwiy al-'Ishrìya, (Kuwait: Shirkah al-Maktabāt al-Kuwaitiyah, 1984), h. 324.

${ }^{25}$ Nancy L. Rosenblum, "Religious Parties, Religious Political Identity, and the Cold Shoulder of Liberal Democratic Thought", h. 25.

${ }^{26}$ M. Hakan Yavuz, Secularism and Muslim Democracy in Turkey, h. 7. 
identitas keagamaan kolektif yang cukup dan/atau menggunakan modal dan simbol keagamaan untuk meraih keunggulan politik secara kolektif". ${ }^{27}$

Secara struktural, sebenarnya partai-partai politik keagamaan tidak berbeda dengan partai-partai politik yang lain. Mereka sama-sama bertujuan untuk meraih kekuasaan, mengontrol pemerintahan, menerapkan ideologi atau program-program politik tertentu, serta memiliki struktur organisasi yang kurang lebih sama pula. Hal yang membedakan mereka dengan partai-partai politikyang lain, demikian Rosenblum menjelaskan, adalah adanya "keyakinan bahwa doktrin agama atau nilai-nilai keagamaan harus memandu setiap aspek kehidupan", dan adanya " hubungan asosiasional antara partai-partai politik itu dengan kelompok-kelompok sosial keagamaan lewat mana mereka menyatukan kegiatan politik dengan kehidupan sosial dan spiritual. Di lihat dari sisi jaringan afiliasi yang saling melengkapi ini, maka partai-partai keagamaan lebih mirip sebagai kelompok jemaat ketimbang partai”. ${ }^{28} \mathrm{Di}$ dalam dunia Islam, dijelaskan oleh Salih, partai-partai Islam, baik yang radikal maupun moderat, berupaya untuk menciptakan suatu masyarakat yang mengabdi, atau setidak-tidaknya dipengaruhi oleh ajaran dan nilai-nilai yang bersumber kepada hukum Islam; di samping, mengedepankan cara pandang kehidupan yang Islami dan melayani kepentingan umat Islam. ${ }^{29}$

Seperti juga partai-partai non-keagamaan lain, partai-partai politik keagamaan dapat dibedakan ke dalam sejumlah tipologi. Gunther dan Diamond membagi partai yang berbasis agama kepada dua jenis yakni: mass-denominational parties (partai-partai massa denominasional) yang berkarakter demokratik, pluralis dan toleran dan religious fundamentalist parties (partai-partai fundamentalis keagamaan) yang berupaya mengorganisir negara dan masyarakat

${ }^{27}$ Kikue Hamayotsu, "Rise and Falls of Religious Parties in Indonesia" dalam Dirk Tomsa, Andreas Ufen, (eds), Party Politics in Southeast Asia: Clientelism and Electoral Competition in Indonesia, Thailand and the Philippines (New York : Routledge, 2013), h. 123.

${ }^{28}$ Nancy L. Rosenblum, "Religious Parties, Religious Political Identity, and the Cold Shoulder of Liberal Democratic Thought”, h. 26, 33.

${ }^{29}$ M.A. Mohamed Salih (ed), Interpreating Islamic Political Parties, (New York: Palgrave MacMillan, 2009), h. 1. 
melalui pemahaman yang ketat terhadap prinsip/doktrin kegamaan. Contoh partai yang masuk dalam kategori pertama adalah : partaipartai Kristen Demokrat yang ada di Jerman, Italia, Belanda, Belgia, Polandia, Chzechnya, Sementara untuk partai dalam kategori kedua adalah : Front Keselamatan Islam (Islamic Salvation Front/ al-Jabhah al-Islāmiyah lil-Inqādh di Aljeria dan Partai Kesejahteraan (Justice Party/Adalet Partisi) di Turki. ${ }^{30}$

Donald Smith, seperti dikutip oleh Johnstone, membagi partai politik keagamaan kepada tiga macam. Pertama, partai-partai komunal (communal parties), contohnya partai Hindu Mahasabha atau Jana Sangh di India. Kedua, partai berbasis sekte ( sect-based party) seperti partai Ummah di Sudan. Ketiga, Partai ideologi keagamaan (ideological religious party) contohnya partai Kristen Demokrat di Chili dan Partai Masyumi di Indonesia. ${ }^{31}$ Khusus untuk kalangan Islam, Vali Nasr membagi partai-partai Islam kepada dua jenis, yakni : partai-partai yang berorientasi Islam (Muslim demokrat) dan partaipartai Islamis. Tidak seperti kelompok Islamis yang bertujuan untuk menerapkan syariat dan menghidupkan kembali kehalifahan, demikian Nasr menjelaskan, Muslim demokrat memandang kehidupan politik dari kacamata pragmatis dan menolak, atau setidak-tidaknya mengurangi, klaim klasik kaum Islamis yang mengatakan bahwa agama Islam mewajibkan (umatnya) untuk membangun negara syari'at. Tujuan utama mereka lebih bersifat keduniawian yakni menyusun flatform elektoral yang dapat dijalankan serta membentuk koalisi pemerintahan yang stabil untuk melayani kepentingan individu dan masyarakat - Muslim atau nonmuslim- dalam suatu arena yang demokratis. ${ }^{32}$

\section{Persepsi Masyarakat terhadap Partai Keagamaan}

Meski eksistensi agama telah lama menyatu dalam realitas sosial, namun keberadaan partai agama di dunia politik belum sepenuhnya memperoleh dukungan baik dari lembaga negara

\footnotetext{
${ }^{30}$ Richard Gunther dan Larry Diamond, "Species of Political Parties : A New Typology”, Party Politics Vol. 9. No.2 (2003), h. 182-183.

${ }^{31}$ Ronald L. Johnstone, Religion and Society in Interaction : the Sociology of Religion , ( New Jersey: Prentice, 1975), h. 203-204.

${ }^{32}$ Vali Nasr, “The Rise of “Muslim Democracy”." Journal of Democracy, vol. 16, No. 2 (2005), h. 16-17.
} 
maupun dari kalangan intelektual. Di negara-negara sekuler tegas (assertive secularism) ${ }^{33}$ seperti Perancis, Turki, Bulgaria, kehadiran partai politik keagamaan dilarang secara konstitusional. Hanya di negara-negara sekuler pasif(passive secularism) seperti Inggris, Amerika Serikat, Australia, dan sejumlah negara Barat lainnya, kehadiran mereka ditolerir meski dengan beberapa batasan tertentu. ${ }^{34}$

Amy Gutmann adalah satu di antara sejumlah ilmuwan yang menolak kehadiran agama dalam ranah politis.Ia menyatakan dengan tegas bahwa terdapat alasan yang kuat untuk memisahkan agama dari (kehidupan) politik sehari-hari sehingga identitas keagamaan tidak lagi menjadi bahan pertikaian politik. ${ }^{35}$ Penolakan senada juga dilakukan oleh Robert Audi yang mengajukan delapan alasan mengapa agama harus dipisah dari panggung politik, ${ }^{36} \mathrm{Di}$ Indonesia, penolakan serupa pernah dikumandangkan oleh Nurcholis Majid dengan jargonnya yang terkenal "Islam Yes, partai Islam No." ${ }^{37}$

Berbeda dengan pandangan para ilmuwan di atas, para ilmuwan lain seperti : Rosenblum, Mueller, Anke Schuster, Nicholas Wolterstorff, Sabah Mofidi, Yūsuf al-Qaradāwì, al-Khidar Husain dan sejumlah ilmuwan lainnya, justru mendukung kehadiran agama dalam panggung politik. Rosenblum berpendapat bahwa 'di alam

33 Istilah ini pertama kali diperkenalkan oleh Ahmet Kuru melalui tulisannya yang berjudul "Passive and Assertive Secularism: Historical Conditions, Ideological Struggles, and State Policies toward Religion “, World Politics 59 ( July 2007), h. 568-94.

${ }^{34}$ Nancy L. Rosenblum, "Banning Parties: Religious and Ethnic Partisanship in Multicultural Democracies”, Law \& Ethics of Human Rights, vol.1. 1 (2007), h. 36.

35 Amy Gutman, Identity in Democracy, (Princeton: Princeton University Press,2003), h. 152.

${ }^{36}$ Delapan alasan tersebut adalah : 1. Infallible Supreme Authority (Otoritas agung yang tidak bisa salah). 2. Condemnatory tendencies (Kecenderungan untuk menyalahkan). 3. The threat of religious domination (Ancaman dominasi keagamaan), 4. Cults and the specters of fanaticism (Sekte dan hantu fanatisme); 5. Dangers of an inflated sense of self-important ( Bahaya melambungnya perasaan pentingnya diri sendiri); 6 . Passionate concern with outsiders ( Keprihatinan yang menggebu-gebu terhadap orang luar); 7. Centrality and delicacy of religious liberty (Sentralitas dan rumitnya kebebasan beragama); 8. Intergenerationality (kesambungan antar generasi. Baca : Robert Audi, Religious Commitment and Secular Reason, (Cambridge : Cambrige University Press, 2000), h. 100-103.

${ }^{37}$ Nurcholish Madjid, Islam Kemodernan dan Keindonesiaan (Bandung: PT Mizan Pustaka, 2008), h. 226-227. 
demokrasi "agama dalam dunia politik" memiliki potensi untuk (mendorong) akulturasi demokratis. Paling tidak, partai-partai etnik dan keagamaan merefleksikan logika denominasionalisme yang dapat diterapkan ke dunia politik; di mana mereka menerima bahwa keyakinan mereka bukan satu-satunya atau bersifat universal. Memasuki dunia politik elektoral membutuhkan ketegasan bahwa apa yang baik bagi untuk kelompok harus juga baik untuk publik dan (tidak mendatangkan keburukan untuk publik). ${ }^{38}$ Dalam tulisannya yang lain, Rosenblum justru menengarai bahwa 'setiap langkah untuk melarang partai (agama/etnik) senantiasa diwarnai oleh unsur nafsu guna mendapatkan atau mempertahankan kekuasaan, kebencian dan pengucilan, dan ketakutan terhadap subversi. ${ }^{39}$ Sama seperti Rosenblum, Mueller juga menegaskan ' Partai-partai agama, seperti juga partai-partai lainnya, muncul untuk mengedepankan kepentingan para pendukungnya, dan, karena itu, mereka tidak lebih berbahaya seperti partai-partai yang lainnya. ${ }^{40}$ Schuster bahkan menegaskan "Melarang partai keagamaan hanya akan mendatangkan lebih banyak keburukan daripada manfaat... memberi toleransi kepada partai agama lebih sedikit bahayanya dibanding melarangnya." ${ }^{41}$

Dari kalangan ilmuwan Muslim, Sabah Mofidi menegaskan, agama memiliki sejumlah fungsi yang positif dalam dunia politik. Ia dapat berfungsi sebagai pendorong partisipasi politik, sebagai simbolisasi dan ideologi, sebagai alat integrasi, solidaritas dan tatanan politik, sebagai alat pemusatan kekuasaan, dan beberapa fungsi positif lainnya. ${ }^{42}$ Yūsuf al-Qaradāwimenegaskan jika agama masuk dalam kancah perpolitikan, ia tidak akan mendatangkan keburukan kepada dunia politik atau pada agama itu sendiri. Sesungguhnya jika agama yang benar masuk ke dalam dunia politik

${ }^{38}$ Nancy L. Rosenblum, On the Sides of the Angels, (Princeton : Princeton University Press, 2008), h. 452.

${ }^{39}$ Nancy L. Rosenblum, "Banning Parties:..., h. 71.

40 Dennis C. Mueller, Religious Parties (Vienna, Mimeo : University of Vienna, 2012), h. 1.

${ }^{41}$ Anke Schuster, Public Reason and Religious Arguments, (Netherland : Wöhrmann Print Service, 2009), h. 156.

${ }^{42}$ Sabah Mofidi, "The Positive Aspects of Political Function of Religion: An Overview", International Journal of Political Science, Law and International Relations (IJPSLIR), Vol. 3, Issue 2, (Jun 2013), h. 9-20. 
maka ia akan mengarahkan kepada kebaikan, memberi petunjuk kepada jalan yang lurus, menjelaskan makna kebenaran, menjaga dari kesesatan dan kebinasaan. ${ }^{43} \mathrm{Al}-\mathrm{Khidar}$ Husain, seperti dikutip oleh al-Qaradāwỉ, menyatakan dengan tegas bahwa memisahkan agama dari politik sama dengan membongkar sebagian besar hakikat agama, dan tidak memberikan apa-apa bagi kaum muslimin kecuali membuat mereka menjadi bukan muslim. ${ }^{44}$

Perbedaan sikap lembaga negara dan kaum ilmuwan terhadap partai keagamaan di atas, diikuti pula dengan perbedaan persepsi di kalangan masyarakat. Pew Research Center baru-baru ini merilis hasil survey terbaru tentang bagaimana persepsi masyarakat muslim terhadap keberadaan partai-partai Islam di negaranya. Dari survey tersebut diketahui bahwa partai Islam tidak sepenuhnya memperoleh citra yang positif dari umat Muslim setempat. Hal ini ditunjukkan dengan kenyataan bahwa dari sembilan belas negara Muslim yang disurvey, hanya di tujuh negara (Malaysia, Bangladesh, Afghanistan, Mesir, Yordania, Tunisia, dan Maroko) mayoritas responden menyatakan partai Islam lebih baik daripada partai sekuler; Sementara di sebelas negara (Bosnia-Herzegovina, Kosovo, Kirgistan, Tajikistan, Turki, Kazakhstan, Pakistan, Lebanon, Irak, Palestina dan Indonesia) mayoritas responden menyatakan partai Islam sama saja dengan partai Sekuler: Sedangkan di Azerbaijan partai Islam justru dipandang lebih buruk dari partai sekuler. Tiga macam persepsi masyarakat yang demikian ini jelas menunjukkan bahwa partai-partai Islam belum sepenuhnya mendapat tanggapan yang positif dari masyarakat sekitarnya, yang ini boleh jadi karena kinerja partai-partai tersebut tidak maksimal atau boleh jadi juga karena dipengaruhi oleh beberapa faktor lain seperti diketengahkan dalam uraian selanjutnya.

\section{E. Perkembangan Partai Politik Kegamaan di Dunia Barat dan Islam}

Partai agama, seperti yang umum terjadi juga di kalangan partai-partai sekuler lainnya, mengalami periode pasang surut.

${ }^{43} Y \bar{u}$ suf al-Qaradāwì, Al-Dīn wa al-Siyāsah: Ta'sīl wa Radd al-Shubhāt, (Kairo: Dār al-Shurūq, 2007), h. 75-76.

${ }^{44}$ Ibid., h. 84. 
Di dunia Barat, di mana populasi umat Nasrani menduduki posisi mayoritas, dan di Timur, di mana umat Islam mendominasi jumlah penduduk, partai-partai keagamaan tidak menampakkan perkembangan yang signifikan, bahkan dari waktu ke waktu justru cenderung menurun.

Di Finlandia, misalnya, partai Kristen Demokrat Finlandia/ Suomen Kristillisdemokraatit (SKL), sejak kemunculannya di tahun 1958 hingga kini, hanya mampu meraih suara berkisar antara 3\% hingga 5\%. ${ }^{45}$ Demikian juga di Denmark; partai Rakyat Kristen/ Kristeligt Folkeparti (KRF) sejak pertama kali mengikuti pemilu di tahun 1971 hanya satu kali pernah meraih suara di atas 5 \% yakni (5,3\% pada pemilu 1975). Di luar itu, partai ini hanya mampu meraih suara berkisar antara 2 s.d $3 \%$ saja. Bahkan, setelah berganti nama menjadi partai Kristen Demokrat/Kristendemokraterne (KD), perolehan suaranya justru berada di bawah $2 \%$ dan akhirnya menghilang dari arena politik. ${ }^{46}$

Di Swedia, partai Kristen Demokrat/Kristdemokraterna (KD), yang telah mengalami dua kali pergantian nama- pada tahun 1964 bernama partai Persatuan Kristen Demokrat/Kristen Demokratisk Samling (KDS) kemudian pada tahun 1987 berganti nama menjadi partai Kristen Sosial Demokrat/Kristdemokratiska Samhällspartiet (KdS)- baru berhasil memiliki wakil di parlemen setelah tahun 1988 dan memperoleh suara tertinggi pada pemilu 1998 (11,8 \%). Setelah itu, perolehan suara mengalami penurunan sehingga pada pemilu tahun 2010 partai ini hanya berhasil meraih 5,6 \% suara. ${ }^{47}$

Di negara-negara lain, dimana partai keagamaan (Kristen) begitu dominan, perkembangan yang ada juga tidak lebih baik. Di Austria, sebagai salah satu contoh, partai ÖPV( Ósterreichische Volkpartei ) yang berhasil meraih suara sebesar 49,8\% pada pemilu tahun 1945, mengalami penurunan rata-rata $2 \%$ per-pemilu, sehingga pada pemilu 2008 partai ini hanya berhasil mendapatkan $26 \%$ suara. ${ }^{48}$ Hal yang sama terjadi juga di beberapa negara Eropa lainnya. Di Italia, misalnya, partai Kristen Demokrat/Partito Democratito (PD) yang

${ }^{45}$ Wolfram Nordsieck, Parties and election in Europe (Finland) diakses melalui http://www.parties-and-elections.eu/countries.html tanggal 12 Mei 2013 jam 19.00.

${ }^{46}$ Ibid

${ }^{47}$ Ibid

${ }^{48}$ Ibid 
menguasai pemerintahan selama hampir lima dekade (1945 hingga 1992), terpaksa harus keluar dari arena politik setelah terlibat dalam skandal korupsi. Posisi partai ini kemudian digantikan oleh partai Rakyat Merdeka/II Popolo della Liberta (PDL), yang juga merupakan partai Kristen Demokrat, yang berhasil meraih suara sebesar 37,4\% pada pemilu 2008 namun turun menjadi 21,6\% pada pemilu 2013. ${ }^{49}$

Di Jerman, dua partai Kristen terbesar di negara itu yakni, partai Uni Kristen Demokrat Jerman/Christlich Demokratische Union Deutschlands (CDU) dan partai Uni Kristen Sosial Bavaria/ChristlichSoziale Union in Bayern (CSU) pernah berjaya selama 34 tahun (19491983) dengan perolehan suara masing-masing $38 \%$ untuk CDU dan 10,6 \% untuk CSU pada pemilu 1983. Namun setelah periode itu, kedua partai tersebut secara berangsur-angsur kehilangan popularitas, sehingga pada pemilu tahun 2009 partai CDU hanya berhasil meraup 27,3 \% suara dan CSU mendapatkan 6,5 \%.50

Di Belgia, dua partai Kristen terbesar, yakni Partai Rakyat Kristen/Christelijke Volkspartij (CVP) dan partai Kristen Sosialis/Parti Social Chrétien (PSC), mendominasi perolehan suara selama pemilu periode 1946 hingga 1978. Namun, setelah itu, perolehan suara kedua partai tersebut terus mengalami penurunan, sehingga pada tahun 2002 mereka terpaksa berganti nama- Partai CVP berganti nama menjadi CD\&V (Christen-Democratisch en Vlaams) dan PSC menjadi cdH (Centre démocrate humaniste). Pergantian nama ini nyatanya tidak banyak berpengaruh, karena pada pemilu 2003 CD\&V hanya meraih suara $13,3 \%$ dan cdH hanya memperoleh $5,5 \%$, bahkan pada pemilu $2010 \mathrm{CD} \& \mathrm{~V}$ hanya berhasil mengantongi 10,9\% suara dan cdH hanya memperoleh 5,7 \%. ${ }^{51}$

Di Belanda, partai Rakyat Katholik/Katholieke Volkspartij (KVP) pada pemilu tahun 1946, berhasil meraup suara sebesar 30,8\%. Tetapi sejak pemilu 1960 partai ini terus-menerus kehilangan suara, sehingga pada pemilu tahun 1972 partai ini hanya memperoleh suara sebesar 17,7 \%. Setelah itu, KVP bergabung dengan partai Persatuan Kristen Historis/Christelijk-Historische Uni (CHU) dan membentuk

${ }^{49} \mathrm{Ibid}$
${ }^{50} \mathrm{Ibid}$
${ }^{51} \mathrm{Ibid}$ 
partai Kristen Demokratik/Christen Democratische Appêal (CDA), yang berhasil meraup suara $31,9 \%$ pada pemilu 1977. Namun, seperti juga partai-partai agama lainnya, CDA terus menerus kehilangan pendukungnya, sehingga pada pemilu 2010 partai ini hanya berhasil meraih suara $13,7 \%$ dan turun lagi menjadi $8,5 \%$ pada pemilu 2012.52

Melemahnya perkembangan partai-partai keagamaan di negara-negara Barat bukan merupakan satu-satunya fenomena yang terjadi di dunia politik. Di sejumlah negara dalam dunia Islam, kecuali di Turki, Mesir dan Palestina, gejala menurunnya elektabilitaspartai-partaipolitikIslamdalamkompetisielektoralpun dapat ditemukan. Seperti dikemukakakan oleh Kurzman dari 86 even pemilu dalam mana partai-partai Islam turut serta, besaran perolehan suara yang mereka capai rata-rata hanya sebesar 12,2 $\%$ atau $13.2 \%$ untuk peraihan kursi di parlemen. Angka inipun setelah digabung dengan keberhasilan di tiga negara di atas. Jika diambil nilai median sebagai indikator, separuh dari partai-partai Islam yang ikut serta dalam even-even pemilu tersebut paling tinggi perolehannya hanya mencapai 8,9\% suara atau 9,2 \% kursi di parlemen. ${ }^{53}$,

Contoh lebih konkrit lagi adalah seperti yang terjadi di Aljeria, Pakistan dan Indonesia. Di Aljeria, total suara kumulatif yang di peroleh partai-partai Islam pada pemilu 1991 mencapai $\pm 55 \%$. Tetapi pada pemilu 1997, suara kumulatif yang diperoleh turun drastis menjadi $\pm 24 \%$. Pada pemilu berikutnya, penurunan kembali terjadi menjadi : $\pm 17 \%$ di tahun 2002 , $\pm 15,56 \%$, pada pemilu 2007, dan terakhir pada pemilu 2012 partai-partai Islam di Aljeria hanya berhasil meraih $\pm 9,27$ \% suara. Hal yang sama terjadi di Pakistan. Pada pemilu 1997 partai-partai Islam Pakistan menguasai $\pm 50,9 \%$ suara; Namun pada pemilu 2003 perolehan itu menurun menjadi $\pm 48,2 \%$, pemilu 2008 menjadi $\pm 46,96 \%$ dan terakhir (pemilu 2003) hanya memperoleh $44,02 \%$ suara. ${ }^{54}$

${ }^{52}$ Ibid

53 Charles Kurzman dan Ijlal Naqvi. "Islamic Political Parties And Parliamentary Election.” United States Institute of Peace, Working Paper no. 15 (2009), h. 3.

${ }^{54}$ Data diolah dari hasil pemilu di dua negara tersebut yang diakses melalui http://en.wikipedia.org/ wiki/Elections by country pada tanggal 12 Juni 2013 
Sementara di Indonesia, setelah jatuhnya rejim Suharto, perolehan suara partai-partai Islam, di luar PKB dan PAN, menurun secara fluktuatif. Hal mana pada pemilu 1999 perolehan suara yang dicapai secara kumulatif sebesar $\pm 16,63 \%$; pada pemilu 2004 naik menjadi $\pm 21,34$; kemudian pada pemilu 2009 turun lagi menjadi $\pm 18,21 \%$. ${ }^{55}$ Sementara untuk pemilu 2014, beberapa pengamat meramalkan perolehan suara yang akan dicapai partai-partai Islam kembali akan menurun, bahkan merosot jauh. ${ }^{56}$

\section{F. Beberapa Perspektif tentang Penyebab Merosotnya Partai Keagamaan}

Mengapa elektabilitas partai keagamaan di dunia terus menurun? Kebanyakan penulis, termasuk di antaranya Ronald Inglehart dan Kurt R. Luther, meyakini proses sekularisasi sebagai faktor penyebabnya. ${ }^{57}$ Pendapat ini, meski dianut oleh banyak ilmuwan, sebenarnya memiliki beberapa kelemahan. Pertama, seperti diakui sendiri oleh Inglehart, fakta-fakta yang mendukung argumentasi tersebut hanya terjadi di dunia Barat, khususnya di negara-negara industri maju: ${ }^{58}$ Dus, tidak dapat digeneralisasi. Kedua, seperti diakui oleh Peter L. Berger, teori sekularisasi yang mengklaim bahwa modernisasi mengakibatkan peran agama menurun ternyata salah; justru sebaliknya di banyak tempat sekarang ini sedang berlangsung proses de-sekularisasi. ${ }^{59}$

jam 20.00 WIB.

${ }_{55}$ Penghitungan diolah berdasarkan kepada data hasil pemilu yang bersumber dari KPU Pusat tanpa mengikut sertakan partai PAN dan PKB..

${ }^{56}$ LIPI merilis hasil survei nasional mengenai partisipasi politik dan perilaku memilih pra-Pemilu 2014. Survei yang dilakukan pada 10-31 Mei 2013 itu menjelaskan bahwa PPP dan PKS masing masing akan berada di peringkat ke-enam dan ke-tujuh; PPP 2,9 persen. Sementara PKS diperkirakan akan meraih 2,6 persen suara.

${ }^{57}$ Baca Pippa Norris dan Ronald Inglehart, Sacred and Secular: Religion and Politics Worldwide, (Cambridge: University of Cambridge, 2004), h. 196-212, dan Kurt R. Luther dan K. Deschouwer, "Prudent Leadeship' to Succesful Adaptation?" dalam Kurt R. Luther dan K. Deschouwer (eds), Party Elites in Divided Societies: Political Parties in Consociational Democracy, (London: Routledge, 1999), h. 248.

${ }^{58}$ Pippa Norris dan Ronald Inglehart, Sacred and Secular..., h. 212.

${ }^{59}$ Baca Peter L. Berger, " The Desecularization of the World : A Global Overview " dalam Peter L. Berger (ed), The Desecularization of the World: Resurgent Religion and World Politics (Washington D.C : Ethics and Public Policy Center, 1999), 
Atas alasan itu, penulis lebih cenderung kepada pandangan Belluci dan Heath yang menawarkan tiga macam pendekatan untuk memahami penyebab pasang/surutnya perkembangan partai. Pertama, melalui hubungan "dari atas ke bawah (top-down)"; kedua melalui hubungan "dari bawah ke atas (bottom-up)", atau melalui pendekatan ketiga, yakni pendekatan "segmentasi” yang mencermati hubungan pertalian (linkage) antara partai dengan kelompok masyarakat. Contoh-contoh faktor dalam dimensi yang pertama antara lain menyangkut masalah kepemimpinan, kaderisasi, kohesi partai terutama di tingkat elite, konflik internal partai, ketersediaan sumber dana, dan lain-lain. Faktor-faktor dalam dimensi yang kedua meliputi aspek regulasi sistim kepartaian, pola kompetisi antar partai, perkembangan/perubahan sosial, ekonomi dan politik, serta beberapa faktor lainnya. Sedangkan faktor-faktor dalam dimensi ke-tiga misalnya : masalah persepsi masyarakat terhadap ideologi/ program partai, effektifitas pencitraan (positioning), posisi partai di tingkat akar rumput, dan beberapa faktor lainnya. ${ }^{60}$

\section{G. Kesimpulan}

Bertitik tolak dari apa yang telah diketengahkan di atas dapat disimpulkan bahwa partai berbasis keagamaan cenderung kalah bersaing dengan partai-partai sekuler dalam meraih dan mempertahankan dukungan masyarakat dalam berbagai event pemilu. Meski di beberapa tempat tertentu gejala ini masih dapat dikecualikan, namun kecenderungan di atas perlu terus dicermati dan disadari oleh para aktivis parpol keagamaan. Dengan kata lain beberapa langkah evaluatif dan konstruktif harus segera diambil jika tidak ingin keberadaan organisasi ini lenyap dalam kancah perpolitikan di masa depan. []

h. 1-18.

${ }^{60}$ Paolo Bellucci dan Oliver Heath, "The Structure of Party-Organization Linkages and the Electoral Strength of Cleavages in Italy 1963-2008”, h. 208. 


\section{Daftar Pustaka}

'Imārah, Muhammad, al-Islām wa Falsafah al-Hukm, Kairo: Dār alShurūq, 1989.

al-Ansarìy, 'Abd al-Hāmid Ismā'il, Al-Sūra wa Atharuha fi al-Dỉmuqrātiyah, Beirut: Mansurāt al-Maktabah alAhdiyah, tt.

al-Hāshimī, Tāriq 'Alī, al-Ahzāb al-Siyāsiyah, Baghdād: Sharikah alTab'i wa al-Nashr, 1968.

al-Hassānỉ Husain Jah̄d, dan al-Husainī, Najāh Jābir, Mashrū'iyah al-Ahzāb fi al-Islām fi Tanzỉri Ayat Allah al-Karabāsỉ, Beirut: Bait al-'Ulūm li al-Nābihin, 2006.

al-Māliki, Fahd ibn 'Abd Allah al-Rabỉ'ah al-Mālikỉ dan Mubārak ibn 'Abd Allah al-Rabi'ah, Mukhtasor al-Tsaqāfah al-Siyāsiyah, Yordan: Dār ibn al-Jawzì, 2013.

al-Qaradāwi, Yūsuf, Al-Dīn wa al-Siyāsah: Ta'sīl wa Radd al-Shubhāt, Kairo: Dār al-Shurūq, 2007.

al-Sāwỉ, Solāh, Tā‘addudiyah al-Siyāsiyah fi Dawlah al-Islmiyah, Kairo: Dār al-I‘lām al-Dawlì, 1993.

Amān, Muhammad dan Sālim, Shawqỉ, Tasnīf Dỉwiy al-'Ishrìya, Kuwait: Shirkah al-Maktabāt al-Kuwaitiyah, 1984.

Audi, Robert, Religious Commitment and Secular Reason, Cambridge: Cambrige University Press, 2000.

Bellucci, Paolo dan Heath, Oliver, "The Structure of PartyOrganization Linkages and the Electoral Strength of Cleavages in Italy 1963-2008".

Berger, Peter L., " The Desecularization of the World : A Global Overview “ dalam Peter L. Berger (ed), The Desecularization of the World: Resurgent Religion and World Politics, Washington D.C : Ethics and Public Policy Center, 1999.

Downs, Anthony, An Economic Theory of Democracy, New York : Harper and Row, 1957.

Duverger, Maurice, Political Parties: Their Organization and Activity in the Modern State, London : Methuen, 1959.

Epstein, Leon D., Political Parties in Western Democracies, New 
Brunswick NJ: Transaction Publishers, 2000.

Gunther, Richard dan Diamond, Larry, "Species of Political Parties:

A New Typology,” Party Politics, vol. 9, no. 2 (2003).

Gutman, Amy, Identity in Democracy, Princeton: Princeton University Press,2003.

Hamayotsu, Kikue, "Rise and Falls of Religious Parties in Indonesia" dalam Dirk Tomsa, Andreas Ufen, (eds), Party Politics in Southeast Asia: Clientelism and Electoral Competition in Indonesia, Thailand and the Philippines, New York: Routledge, 2013.

Hasan, Hasan Ibrāhim, Tàrikh al-Islām al-Siyāsì wa al-Dīnì wa al-Tsaqāfī wa al-Ijtimāīy, Kairo: Maktabah al-Nahdah al-Misriyyah, 1996, Juz II.

http://en.wikipedia.org/wiki/Elections by country pada tanggal 12 Juni 2013 jam 20.00 WIB.

Johnstone, Ronald L., Religion and Society in Interaction : the Sociology of Religion, New Jersey: Prentice, 1975.

Jr., Valdimer O. Key, Public Opinion and American Democracy, New York: Knopf, 1961.

Katz, Richard S. dan Mair, Peter, "Changing Models of Party Organization and Party Democracy: The Emergence of the Cartel Party," Party Politics, vol. 1, no. 1, (1995).

, "The Evolution of Party Organization in Europe: The Three Faces of Party Organization "dalam The American Review of Politics, Vol. 14 (1993).

Kirchheimmer, Otto, "The Transformation of the West European Party Systems", dalam Joseph La Palombara dan Myron Weiner (eds), Political Parties and Political Development, Princeton, N.J.: Princeton University Press, 1966.

Krouwel, André, "Party Models," dalam Richard S. Katz dan William J. Crotty (eds), Handbook of Party Politics, London: Sage Publication Ltd., 2006.

Kuru, Ahmet, "Passive and Assertive Secularism: Historical Conditions, Ideological Struggles, and State Policies toward Religion “, dalam World Politics 59 ( July 2007).

Kurzman, Charles dan Naqvi, Ijlal, "Islamic political parties and 
parliamentary elections." Dalam United States Institute of Peace, Working Paper no. 15 (2009).

Lapalombara, Joseph, dan Anderson, Jeffrey, "political parties" dalam Mary Hawkesworth dan Maurice Kogan (eds), Encyclopedia of Government and Politics, Vol. I, London: Routledge, 1992.

Luther, Kurt R., dan Deschouwer, K., "Prudent Leadeship' to Succesful Adaptation?” dalam Kurt R. Luther dan K. Deschouwer (eds), Party Elites in Divided Societies: Political Parties in Consociational Democracy, London: Routledge, 1999.

Madjid, Nurcholish, Islam Kemodernan dan Keindonesiaan, Bandung: PT Mizan Pustaka, 2008.

Maisel, Louis S., dan Brewer, Mark D., Parties and Elections in America: The Electoral Process, Lanham, Maryland: Rowman \& Littlefield Publishers Inc., 2011.

Manzūr, Muhammad ibn, Lisan al-AArab, Beirut: Dār al-Sādir, 1956, Juz I.

Mofidi, Sabah, "The Positive Aspects of Political Function of Religion: An Overview", dalam International Journal of Political Science, Law and International Relations (IJPSLIR), Vol. 3, Issue 2, (Jun 2013).

Mueller, Dennis C., Religious Parties, Vienna, Mimeo : University of Vienna, 2012.

Nasr, Vali, “The Rise of "Muslim Democracy”." Journal of Democracy, vol. 16, No. 2 (2005).

Nordsieck, Wolfram, Parties and election in Europe (Austria) diakses melalui http://www.parties-and-elections.eu/countries.html tanggal 12 Mei 2013 jam 19.00.

Robbins, Caroline, "Discordant Parties": A Study of the Acceptance of Party by Englishmen," dalam Political Science Quarterly, vol. 73, no.4 (Dec.1958).

Rosenblum, Nancy L., "Banning Parties: Religious and Ethnic Partisanship in Multicultural Democracies", Law \& Ethics of Human Rights, vol.1, No. 1 (2007). 
Rosenblum, On Nancy L., the Sides of the Angels, Princeton: Princeton University Press, 2008.

Rositer, Clinton, Parties and Politics in Americ, Ithaca, NY: Cornell University Press, 1960.

Salih, M.A. Mohamed, (ed), Interpreating Islamic Political Parties, New York: Palgrave MacMillan, 2009.

Sartori, Giovanni, Parties and Party Systems: A Framework for Analyses, Colchester: ECPR Press, 2005.

Schattscheneider, Elmer E., The Struggle for Party Government, College Park MD : University of Maryland, 1948.

, Party Government in the United States, New York: Holt Rinehart and Winston, 1942.

Schlesinger, Joseph A., "Political Party Organization" dalam James G. March (ed) Handbook of Organizations, Chicago: Rand McNally, 1965.

Schuster, Anke, Public Reason and Religious Arguments, Netherland: W hrmann Print Service, 2009.

Wollinetz Steven B., "Beyond the Catch-All Party: Approaches to the Study of Parties and Party Organization in Contemporary Democracies," dalam Richard Gunther, J. Ramon-Montero, dan Juan J. Linz, (eds). Political Parties: Old Concepts and New Challenges, Oxford: Oxford University Press, 2002.

Yavuz, M. Hakan, Secularism and Muslim Democracy in Turkey.

Zaid, Bakr ibn 'Abdillah Abū, "Hukm al-Intimā'i ilā al-Farq wa alAhzāb wa al-Jamā‘āh al-Islāmiyah”, dalam al-Ri'āsah al'Āmmah li Idārāt al-Buhūts al-'Alamiyyah wa al-Iftā'i wa alDa‘wah wa al-Irshād, No. 33/2 (1989. 
Henry Iwansyah 